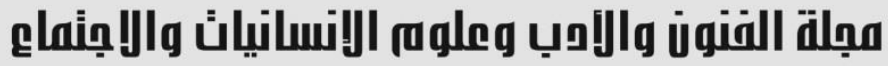

Journal of Arts, Literature, Humanities and Social Sciences

www.jalhss.com

Volume (54) July 2020

العدد (54) يوليو 2020

\section{Reducing Costs by the Use of Cloud Accounting}

\author{
Paiman Ibrahim Ahmed \\ Accounting Department- Erbil Technical Administration Institute \\ Erbil Polytechnic University- Erbil - Iraq \\ Email: paiman.ahmed@epu.edu.iq
}

\begin{abstract}
Cloud technologies have developed intensively during the last years. Cloud accounting is one of the most important factors that assist economic units in keep up of scientific and technological development and its exploitation in the organization of accounting work based on the Internet-based on systems designed to carry out all the accounting procedures of the economic unit, Dematerialization of accounting documents and migration of certain accounting operations to cloud-based electronic platforms have overcome the research phase, as the Kurdistan region already includes numerous companies that develop and provide cloud accounting based accounting applications. The research aims to review the concept of cloud accounting and its advantages. It found that reliance on cloud accounting contributes to cost reduction as well as its contribution to the organization of accounting work. The present research seeks to verify the hypothesis claiming that the cost-saving generated by the utilization of a cloud accounting based application is significant enough to represent a relevant criterion when selecting the internet based accounting solution.
\end{abstract}

Keywords: Cloud accounting, reducing costs. 


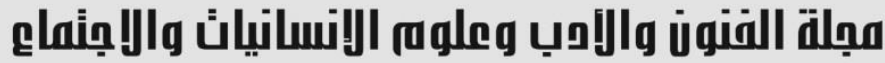

Journal of Arts, Literature, Humanities and Social Sciences

www.jalhss.com

Volume (54) July 2020

العدد (54) يوليو 2020

\section{Introduction}

Accounting, the language and science of measuring business performance, has been continuously adapting to the economic context. During the late 1950s, the automation of accounting data had begun, considering the large volume of information and the necessary time to process it, accounting software became a very facilitative tool for accountants to do their job faster and more efficient. Although accounting software has been around for decades, it has continued to develop its potential over the years; it has become highly sophisticated, and this evolution marches on (Dimitriu \& Matei, 2015, 665-666).

Accounting "in the cloud" is a relatively new phenomenon. Accounting is a field rather conservative and one of the last subjected to modern IT and technological. With the introduction of new solutions in recent years, it turned out that the concept of building owns data centre is not always forceful. Moreover, in the era of globalisation and performance of transnational availability of current financial information from anywhere in the world and at any time becomes a necessity. Processing of data on costs, revenues, sales, corporate finance in the cloud enables access to such data limited only by access privileges independently of place and time (Wyslocka \& Jelonek, 2015, 1). Use of cloud accounting to Reducing the costs of a new business model. The purpose of the paper is to present the numerous facets of this innovative paradigm. Because of the novelty of the concept, the current academic literature does not provide much information on this topic. We could say that the business environment is the one that specifically supported research on cloud-based accounting solutions. For that reason, until now, the articles that refer to the cloud accounting notion are mostly technical reports, surveys and market studies.

\section{1- Concept of Cloud Accounting:}

Historically, accounting systems were the primary driving force behind the demands for IT systems. In recent years, the rise of new, cloud-based accounting software had led to sombre forecasts in the accounting sector. It is little surprise, perhaps, that accounting firms have become particularly interested in the adoption of cloud computing, and an increasing number of accountants began to provide cloudbased accounting solutions to their clients. Yet, despite the rate of development, academic studies that explicitly examined the impact of cloud computing on the accounting industry was virtually non-existent (Ma, 2015, 18). One of the biggest technological trends at the moment is the emergence of cloud technology. The cloud is 


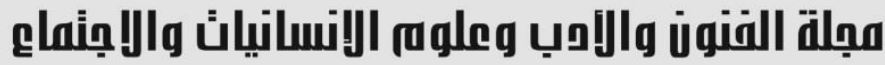 \\ Journal of Arts, Literature, Humanities and Social Sciences www.jalhss.com \\ Volume (54) July 2020 \\ العدد (54) يوليو 2020}

a platform to make data and software accessible online anytime, anywhere, from almost any device having an internet connection (Khanom, 2017, 31).

Cloud accounting is a contemporary concept processing accounting data with a set of the information distribution system and applications in the framework of the concept cloud information without needing for the users to know the physical position and system structuring (Mihalache, 2011, 786). Cloud accounting requires to access to the accounting software and data through an internet browser. Software is provided based on subscription and data is stored in a remote server (ALLAHVERDİ, 2017, 97). It is different from the traditional accounting system require many specific conditions, which makes them too difficult to manage and too expensive for small businesses (Mihalache, 2011, 786). Today's accounting model implies ease of access, customisation, collaboration and ultimately, the use of the Internet through cloud computing. The basic principles that drive cloud computing, combined with the activities carried out by accounting software companies, have led to the emergence of cloud accounting. This concept, also referred to as 'online accounting', involves the same functionalities as an accounting software installed on the client's computer, but which actually runs on the CSP's servers. Basically, it provides accounting services using cloud computing solutions (Dimitriua \& Matei, 2015, 666).

They defined cloud accounting as the use of cloud computing on the internet to build a virtual accounting information system. That is to say, cloud computing plus accounting equals cloud accounting (Zhang \& Gu, 2013, 142). The concept cloud accounting can be defined as the use of online software, storage of the data rather than stored in the physical hard disk of a computer in remote of the server, and access from any internet- connected device to it to manage the records of the enterprise (ALLAHVERDİ, 2017, 97). Access to cloud accounting applications and data is controlled by access of the user to login access instead of the physical position of the files. This means that data sharing is easier for physically carrying data from a computer to the other (Onyali, 2016, 114). Which have been in Figure 1: 


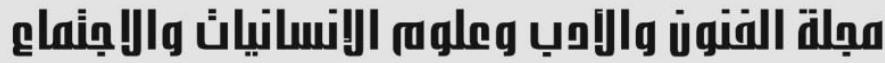

Journal of Arts, Literature, Humanities and Social Sciences www.jalhss.com

Volume (54) July 2020

العدد (54) يوليو 2020
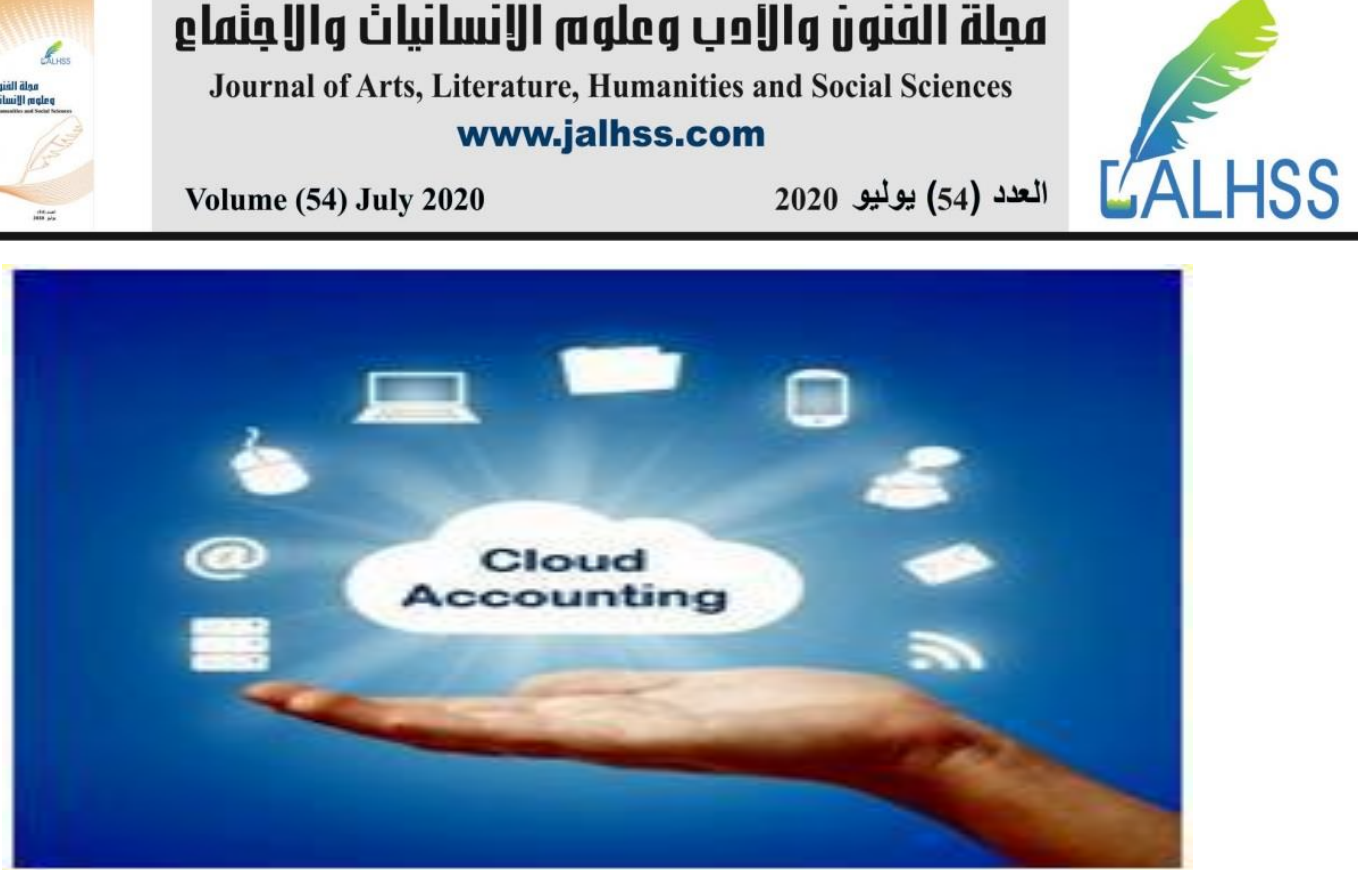

Figure 1: cloud accounting (Modi, 2018, 1091)

\section{2- Benefits of cloud accounting:-}

Cloud accounting has taken the accounting profession into a whole new dimension. Clients can be benefited in many ways by using the cloud accounting system. Some of the major benefits of cloud accounting are given below (Sobhan, 2019, 1263):

1- Lower Cost: Traditional accounting is outscored by cloud accounting in terms of cost. In a cloud accounting system, a client firm does not need to invest in capital expenditures like an instalment of equipment or software licenses. Besides, there is no need to deploy additional staffs for maintaining and monitoring the equipment and software. Another reason why cloud accounting is cheaper than traditional accounting is that the client can use the 'pay per use' service and need not pay any fee in excess of the usage amount. This benefit is particularly important for new and small businesses where being cost effective is very important.

2- Easy Access to All Information: Another benefit of cloud accounting is that it can be easily accessed and the client can use all the available accounting information. Unlike traditional accounting, the user does not have to rely on financial statements or spot-checking of company records in order to have updated information about a business. The user can easily collect and monitor the financial information sitting at home with the help of a mobile or a computer. Besides, cloud accounting provides users with 24/7 access to the services that been provided by the server of the vendor.

3- Increased Security: An important benefit of cloud accounting is that it ensures better security of the financial data of a company. Data stored at the client's company is always at the risk of being attacked by different viruses or 


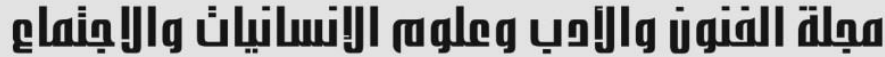

Journal of Arts, Literature, Humanities and Social Sciences

www.jalhss.com

Volume (54) July 2020

العدد (54) يوليو 2020

stolen by employees having low morale. But cloud accounting provides better security by including multiple layers of protections like passwords and other security checks for getting access to the data.

4- Large Storage and Automatic Backups: In a large organisation with a huge amount of daily transactions, it is very difficult to store and maintain all the data. Besides, there is always a risk of losing important data due to employee error or accident. But cloud accounting offers a huge amount of storage capacity to store all the data of the client firm. Besides, its auto backup feature makes it more reliable and a safe source for storing data.

5- Flexibility: Another important benefit of cloud accounting is its flexibility (Mohanty and Mishra, 2017). It is compatible with different types of web browsing software and operating systems. It can be accessed through Windows, Mac or Linux. It can also be used to run through Chrome, Firefox, Internet Explorer or other browsing software. Besides, the IaaS and PaaS enable the client to customise the software based on their own need. As a result, it is becoming very popular in the business sector.

\section{Drawbacks of cloud technology:}

Some of the major shortcomings of cloud technology are (Khanom, 2017, 34$35)$ :

1- Cloud technology requires a constant internet connection which may not be possible always.

2- It does not work well at low speed.

3- Security is another major concern for using the cloud because there may be data, including confidential files which may become viral due to service disruption.

4- As cloud storage becomes more and more familiar, the data they hold becomes more and more of a target. When someone is turning data over to the cloud, it is entrusted to a group of people who will never be me. Some companies usually of large size with lots of sensitive data such as banks and healthcare institutions - would benefit from keeping their data safe to home.

5- By allowing working remotely while travelling, maybe a matter of risk; however, as unsecured Wi-Fi connections may allow unwanted people to access the data. If someone owns a small company, a larger online service may actually be able to provide with more security than she can manage by her self. 


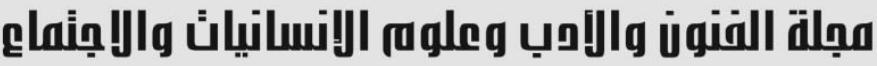 Journal of Arts, Literature, Humanities and Social Sciences www.jalhss.com

6- Many finance and technology leaders fear moving from an on-premises financial system to something unfamiliar like Cloud ERP, holding concerns over the timing and process of software updates, ownership and location of financial data, backup and recovery, availability, security, and getting used to a new system. This is largely a fallacy. Much of the confusion about the Cloud is spread by legacy software vendors who lack solutions with the true multitenant cloud architecture. Many of the risks of moving to the Cloud put forth by legacy vendors are unjustified.

\section{3- Cloud accounting vs traditional accounting}

1- Cloud accounting firms follow the same financial standards as traditional accountants. The tools are different, but the policies they abide by are the same. The standards are created by the Financial Accounting Standards Board, which establishes how private companies prepare their financial reports. The Securities and Exchange Commission governs the accounting practices of public entities, but it has historically based its policies on the accounting model the private sector provides.

\section{https://smallbusiness.chron.com/cloud-accounting-33995.html}

2- Cloud accounting provides online accounting services through the Internet platform, so compared with the traditional accounting information system, it has an absolute advantage in input costs, maintenance costs, barriers to entry, and data reliability, as well as easy to promote in the enterprise.

3- Low input costs: Traditional enterprise accounting information system is the general software for enterprise self-development and purchasing commercialisation. Charges of genuine software are based on modules, ranging from thirty or fifty thousand to as much as hundreds of thousands RMB, but modules the company purchased are not usually used entirely, resulting in great wastage. In addition, companies are also required to invest large sums of money to purchase hardware facility including server, computer room, and data centre. In initial phase, enterprises are required to invest a substantial sum of money in hardware and software facilities. The "Cloud Accounting" belongs to software services, so companies are only required to purchase it according to their needs and pay relatively low "monthly fee" or "annual rental". Companies are not required to pay for one-time investment which can effectively alleviate the financial pressure.

4- Less maintenance costs: As traditional accounting information system requires a lot of hardware infrastructure, we need to consider the security issues of these facilities and accounting information systems. Companies need to set 


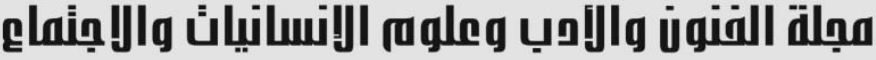 \\ Journal of Arts, Literature, Humanities and Social Sciences www.jalhss.com \\ Volume (54) July 2020 \\ العدد (54) يوليو 2020}

aside large amounts of time, money and human resources on maintaining the normal operation of the equipment. Meanwhile, due to the complexity of the upgrade of software, companies also need to spend a lot of time on software upgrades and maintenance, and constantly facing bottlenecks which occurred during usage, affecting the normal operation of the software. As the "cloud accounting" is leased, only the payment for rent is required. Companies do not need to bear the cost of depreciation of hardware because of one-time investment, as well as not having to pay for professional maintenance and management, which reduces corporate spending on maintenance of accounting information to a large extent.

5- Low barriers to entry: The traditional financial accounting information software requires the operator to receive a long professional training in order to master the operation method of the software, and when a software problem occurs, professional staff is required to carry out the maintenance. When the relevant criteria changes and the software has not been updated in time, the financial staff will have to be re-trained in order to respond to changes in the criteria, and requirements for financial personnel will become higher, which brings inconvenience to the enterprise. When using "cloud accounting" services, it is very simple for companies to operate online, following the instructions, and does not require specialised training. When accounting standards require companies to adopt new accounting treatment, cloud accounting service providers can update the product online in time, and companies can consist with GAAP in a timely manner. Meanwhile, service suppliers also provide professional accounting information technology consultation for companies, so financial officers do not need to be too concerned over the lack of software maintenance knowledge and financial expertise knowledge, and the requirements for access become lower (ZHANG, 2014, 79- 80). Differences in the application of traditional and cloud-based are shown in Table 1.

Table1. Differences in the application of traditional and cloud

\begin{tabular}{|l|l|l|}
\hline & License only & Cloud based solution \\
\hline $\begin{array}{l}\text { Accounting software } \\
\text { license }\end{array}$ & Company's own & Company rent it \\
\hline System location & Where company want it & In the cloud \\
\hline Hardware & Provided by company & In the cloud \\
\hline Windows \& SQL Server & Provided by company & In the cloud \\
\hline Maintenance fees & Purchased & In the cloud \\
\hline
\end{tabular}




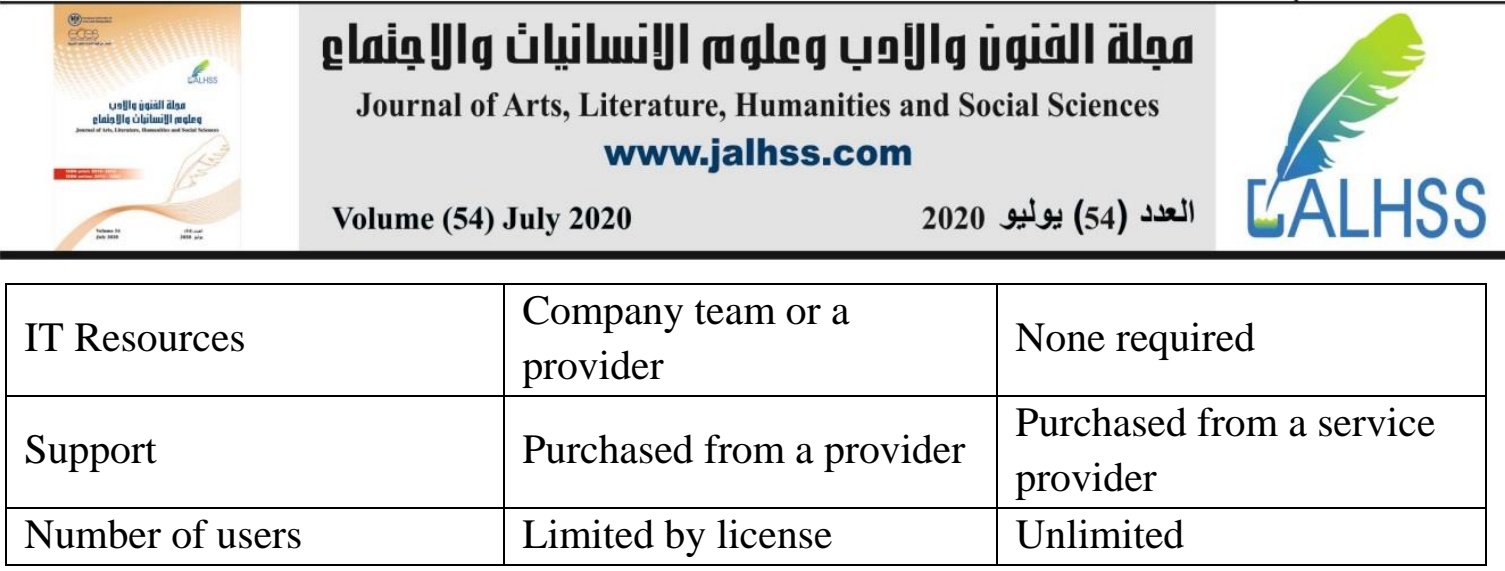

Source: (Dordevic, Radovic \& Bonic, 2018, 25)

\section{Suitability of Cloud Accounting:-}

Both cloud and traditional accounting software have their own benefits, both of which should be considered when making a purchasing decision. Following businesses will fall into the category where cloud accounting may be suitable to use and bring more advantages to them (Khanom, 2017, 35):

- Companies that have a small budget, since it often costs less over time to invest in cloud accounting software than traditional accounting software.

- Businesses with employees who work remotely, since they may prefer the convenience and accessibility of a cloud solution.

- Small companies who cannot provide themselves with adequate security, since many cloud computing companies can keep their information safer from security threats than they can.

- Businesses that want to avoid any potential physical mishaps with technology at an office that could destroy hard drives and, thus, data (fire, flood, burglary, etc.)

Despite the benefits of cloud accounting, some businesses may still prefer to utilize traditional accounting software. Some situations where traditional software might be beneficial include the following:

- Business who want tight control over accounting data and don't want it accessed anywhere there is a non-secure wireless network or where they cannot directly monitor usage.

- Companies that hold very sensitive financial information (banks, etc.), because they don't want any third-parties to have access to it, and they can completely control the level of security by keeping it in-house.

- Businesses with an uncertain future, since many cloud accounting software programs require a company to sign a usage contract — which can be problematic for a company that doesn't know how long it's going to be around.

Intact, one of the big cloud accounting software and web based financial management software providers, has classified, in a study published in 2012, the available options in choosing the accounting application in three categories, as described below (IONESCU \& IONESCU, 2013, 109- 110): 


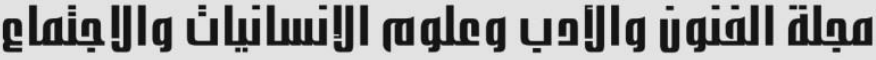 \\ Journal of Arts, Literature, Humanities and Social Sciences \\ www.jalhss.com \\ Volume (54) July 2020 \\ العدد (54) يوليو 2020}

1. On premises - the company purchases a certain software product, which is installed and run using the company's IT logistics. Implementation of the on-premises software is a viable option only for those companies that dispose of the necessary IT infrastructure, capital investments, as well as of significant experience in support and maintenance of such software applications. However, for small and medium-sized companies, operating and capital expenses associated with the development, customization, integration, maintenance and update of such software applications proved to be hard to cover.

2. Hosted solutions - in a hosted environment, the software is physically placed in a remote data center, and run by a third party hosting provider, thus discharging the responsibility of owning and maintaining a hardware infrastructure. However, companies are facing the same customization and updating related problems which generate significant costs, as described for the on-premises solution.

3. Cloud computing - also known as Software as a Service (Saas), is a new type of business applications specially-built for the Internet age. The provider of the application develops a collective, scalable system, which is accessed by its users through the internet, without any prior acquisition or installation of hardware resources. Updates are performed on a regular basis by the cloud vendor.

\section{Cloud for Accountants and Other Accounting Professionals:}

The rising popularity of the cloud among the clients is not the only good reason for the accountants to make a switch to cloud technology. There are numbers of other reasons that make practicing accountant better than a traditional accountant. Here are some of those (Kadian, 2017):

- Cloud accountants can access accounting applications and data from anywhere at any time.

- Cloud accountants do not have to rely on the local systems to work on accounting data, saving them the costs incurred on the local infrastructure setup and maintenance.

- Cloud accountants can collaborate with clients, subordinates, etc. to work together on the same file from different locations.

- Data backup is maintained automatically for the cloud accountants.

- Cloud can integrate better with the online bank and payment accounts to allow the automated listing of financial transactions and reducing the data errors on the accountant's end.

\section{Cloud accounting programs:}

The most important cloud accounting programs that can be found on the Internet: 


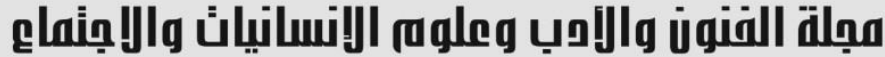

Journal of Arts, Literature, Humanities and Social Sciences

www.jalhss.com

Volume (54) July 2020

العدد (54) يوليو 2020

Fresh Books Accounting: Is an accounting service for small businesses. The solution enables users to send and manage invoices, track billable time and collect online payments. The vendor's value propositions this that their solution provides a straightforward service that simplifies the billing process.

QuickBooks Online: Is a SaaS version of the QuickBooks product. It contains all of the features found in the local version. Higher-priced plans include greater automation, payment management, inventory and time tracking, and analytics features.

Wave: Wave Accounting is a free, cloud-based accounting platform exclusively for small businesses. It supports double-entry bookkeeping and permits unlimited user access, invoicing, and expense management. Wave Accounting integrates with Wave's invoicing, receipt scanning, payment processing and payroll.

Xero: Is an online accounting software product for small businesses and personal finance. Its features beyond general ledger and double-bookkeeping include quotable invoicing, bank reconciliation, purchase order and expense management, and tax management. Third-party apps can extend its features fur.....

Zoho Books: Is an accounting solution that is designed to help small businesses manage their finances. This solution includes dashboards and a wide variety of reports. Business users can automate tasks and set up custom workflows. The vendor offers a 14-day free trial.

Kashoo: Founded in 2008 and based in Vancouver, offers a simple cloud-based double-entry accounting platform for small businesses. It is mobile-accessible and includes many of the typical features required of accounting platforms, including receipt capture, automated invoicing, tax preparation, fin...

OneUp - Is robust cloud-based accounting software that includes CRM and inventory tools. Your sales team can use the software to follow up with leads and create quotes and sales orders, which can then be converted to invoices with a single click. The software tracks inventory and can be set automatically to generate purchase orders when inventory is low. It also runs a variety of reports.

Choosing accounting software can be challenging. Each program includes a different set of features, and most offer multiple pricing plans to choose from, which also vary by feature, number of users, or another factor. Here are three items to keep in mind when selecting accounting software for your business: 


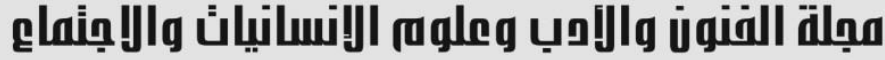 \\ Journal of Arts, Literature, Humanities and Social Sciences www.jalhss.com \\ Volume (54) July 2020 \\ العدد (54) يوليو 2020}

https://www.alignable.com/orlando-fl/forum/can-anyone-recommend-a-good-accountingsoftware-program-for-small/xuerong-liang

1. Costs. Would you prefer inexpensive, basic accounting software or an application that costs more but includes extra features?

2. Usability. How many users need to access the software? Do you prefer a cloudbased system you can access anywhere or desktop software? Do you need it to have a mobile app?

3. Features. What do you need the accounting software program to do? Do you need both accounts receivable and accounts payable tools? Which reports do you need it to generate? Do you need it to track inventory? Do you need it to include ancillary services, like time tracking, project management, and payroll?

Table 2. Reducing cost generated by the migration of monthly accounting operations to the cloud

\begin{tabular}{|l|c|c|}
\hline \multicolumn{1}{|c|}{ The operation } & $\begin{array}{c}\text { The proportion of } \\
\text { time available } \\
\text { manual }\end{array}$ & Reducing cost \\
\hline $\begin{array}{l}\text { collection of supporting } \\
\text { documents }\end{array}$ & $\mathbf{1 0} \%$ & $\mathbf{2 5 0 0 0 0}$ \\
\hline $\begin{array}{l}\text { ordering of supporting } \\
\text { documents }\end{array}$ & $\mathbf{1 0} \%$ & $\mathbf{2 5 0 0 0 0}$ \\
\hline $\begin{array}{l}\text { bookkeeping of accounting } \\
\text { documents }\end{array}$ & $\mathbf{1 0 \%}$ & $\mathbf{2 5 0 0 0 0}$ \\
\hline $\begin{array}{l}\text { recording of transactions into } \\
\text { Journals }\end{array}$ & $\mathbf{2 5 \%}$ & $\mathbf{6 2 5 0 0 0}$ \\
\hline $\begin{array}{l}\text { recording of documents into } \\
\text { Accounts Sheets }\end{array}$ & $\mathbf{2 5 \%}$ & $\mathbf{6 2 5 0 0 0}$ \\
\hline elaboration of the Trial balance & $\mathbf{2 0} \%$ & $\mathbf{5 0 0 0 0 0}$ \\
\hline Total & $\mathbf{1 0 0} \%$ & $\mathbf{2 5 0 0 0 0 0 0}$ \\
\hline
\end{tabular}

Moving of the particular phases of accounting processing flow to the cloud can only be executed when respecting certain requirements, for example: legislative, client's ability to interact with equipment for information and dedicated application, the capacity to realise the economic operations particularities, and the clients ${ }^{\text {ee }}$ conception upon taking responsibility of the respective phase. Once these requirements are respected, moving the respective operations to the cloud generate 


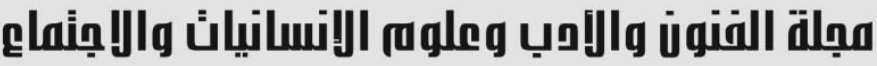 \\ Journal of Arts, Literature, Humanities and Social Sciences www.jalhss.com \\ Volume (54) July 2020 \\ العدد (54) يوليو 2020}

time and resource saving for accounting companies, as well as cost cutting through cloud based processing.

Based on the quantification, in terms of time, of the monthly processing flow phases, and assuming the average customs required by the accounting companies set to $2500000 \mathrm{ID} /$ month services provided to a small or medium sized commercial company, we performed quantification of the potential cost saving generated by moving the accounting operations to the cloud.

The study showed that:

1- Transfer the supporting documentation collection phase to the cloud by managing them through a dedicated application generates cost savings based on the reduction of periodical shifts between the company's clients and the persons generating/operating the documents. As this phase representing 10\% out of the monthly accounting operations can be entirely moved to the cloud, the cost saving generated by the migration would be in the amount of 250000 ID/month for an accounting company.

2- Ranking of the supporting documents can only be automatically performed through the cloud services if the preceding phase was also moved to the cloud. This phase is estimated as weighting $10 \%$ of the monthly accounting operations, it can lead to savings in the amount of $250000 \mathrm{ID} / \mathrm{month}$ for companies using the services of an accounting company.

3- The client can partially use the cloud accounting interface for booking of the supporting documents, given the belief that the client has an acceptable level of understanding of the economic operations particularities, and that the interface provides a grouping of accounts and possible counterparties. As this phase is estimated to weight $10 \%$ out of the monthly accounting operations, it can generate savings in the amount of $250000 \mathrm{ID} /$ month under the use of an accounting company, given that it can be migrated in the percentage of $50 \%$ to the cloud.

4- Booking of transactions in special journals can be moved to the cloud to the extent of $100 \%$, as the application used for booking the transactions can be stored and run on the cloud. We consider that moving up to $100 \%$ of the time used for booking and processing of transactions in journals is possible based on the fact that a client of an accounting company can easily book the amounts on specific journal accounts if the cloud accounting is easy-to-use for cash and banking operations, for supplier clearing operations, for cash disbursement and receipt operations, for inventory movements, for booking of salaries and related contributions, etc. Thus, this phase having an estimated weight of $25 \%$ 


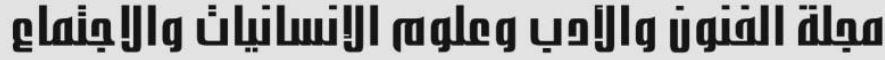 \\ Journal of Arts, Literature, Humanities and Social Sciences www.jalhss.com \\ Volume (54) July 2020 \\ العدد (54) يوليو 2020}

out of the monthly accounting operations, it can generate savings of more than $625000 \mathrm{ID} / \mathrm{month}$ when using the services of an accounting company.

5- If the company uses the traditional information system for accounting purposes, facilities have to be designed and implemented as for the data transfer between the web application and the traditional software, case in which the compatibility of the two systems is an imperative requirement. As this phase is estimated to weight $25 \%$ of the monthly accounting operations and can be entirely moved to the cloud, it can lead to savings in the amount of $625000 \mathrm{ID} /$ month when contracting an accounting company.

6- The trial balance can be moved entirely to the cloud, as it represents an automated step for most of the existing accounting software applications. Similar to the previous phase, this estimated to weight $25 \%$ of the monthly accounting operations and can be entirely moved to the cloud.

Starting with the temporal quantification of the steps followed throughout the annual processing flow, and assuming the average customs used by the accounting companies (8500000 ID), we have quantified the potential cost savings generated by moving the annual accounting processing operations to the cloud.

Table 3. Cost savings generated by the migration of the annual accounting work to the cloud

\begin{tabular}{|l|c|c|c|c|c|}
\hline \multicolumn{1}{|c|}{ The operation } & $\begin{array}{c}\text { Weight in } \\
\text { Total } \\
\text { Annual } \\
\text { operations }\end{array}$ & $\begin{array}{c}\text { Expense } \\
\text { costs } \\
\text { incurred } \\
\text { (customs) }\end{array}$ & $\begin{array}{c}\text { Percentage } \\
\text { of moving } \\
\text { to the cloud }\end{array}$ & $\begin{array}{c}\text { Costs from } \\
\text { using } \\
\text { The cloud }\end{array}$ & Cost saving \\
\hline $\begin{array}{l}\text { General inventory of } \\
\text { assets and debts }\end{array}$ & $10 \%$ & 850000 & $0 \%$ & 850000 & 0 \\
\hline $\begin{array}{l}\text { Checking the accounts, } \\
\text { ending balance }\end{array}$ & $10 \%$ & 850000 & $100 \%$ & 0 & 850000 \\
\hline Accruals transactions & $10 \%$ & 850000 & $50 \%$ & 4250000 & 425000 \\
\hline $\begin{array}{l}\text { Setting out the balance } \\
\text { of accounts after the } \\
\text { inventory and regulatory } \\
\text { operations }\end{array}$ & $10 \%$ & 850000 & $100 \%$ & 0 & 850000 \\
\hline $\begin{array}{l}\text { Determining the profit } \\
\text { or loss, profit } \\
\text { distribution or funding } \\
\text { loss }\end{array}$ & $10 \%$ & 850000 & $100 \%$ & 0 & 850000 \\
\hline
\end{tabular}




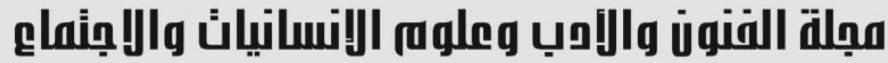

Journal of Arts, Literature, Humanities and Social Sciences

www.jalhss.com

Volume (54) July 2020

العدد (54) يوليو 2020

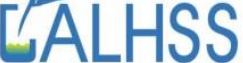

\begin{tabular}{|l|c|c|c|c|c|}
\hline $\begin{array}{l}\text { Setting out the final } \\
\text { balance of Accounts }\end{array}$ & $15 \%$ & 1275000 & $100 \%$ & 0 & 1275000 \\
\hline $\begin{array}{l}\text { Accomplishing the } \\
\text { major financial } \\
\text { statements }\end{array}$ & $20 \%$ & 1700000 & $100 \%$ & 0 & 1700000 \\
\hline $\begin{array}{l}\text { Accomplishing the } \\
\text { annexes to the financial } \\
\text { statements }\end{array}$ & $15 \%$ & 1275000 & $30 \%$ & 382500 & 892500 \\
\hline \multicolumn{1}{|c|}{ TOTAL } & $100 \%$ & 8500000 & & 1657500 & 6842500 \\
\hline
\end{tabular}

The study explains that:

1- The general inventory of assets and liability phase cannot generate cost savings through migration to the cloud, as it cannot be absorbed by an automated process in the cause of need of physical observation (for several asset categories).

2- The balance accounts generation can be entirely moved to the cloud based on the idea that it is already performed through an automated process by most of existing accounting applications, leading to cost savings (850000 ID).

3- Booking of regularisation operations can be moved to the cloud for only $50 \%$, given that the application is used by professionals, Cost saving is (425000 ID).

4- Final balance account generation, as a result of the inventory and regularisation operations, as well as phases regarding computation of the financial profit or loss, profit distribution or loss financing and elaboration of financial situations can be entirely moved to the cloud, as they are already performed through automated processes by most of the traditional accounting applications. Moving these operations to the cloud may lead to cost savings in the amount of (850000 to 0 ID).

5- Elaboration of annexes can be moved to the cloud in the extent of $30 \%$, as certain financial situations annexes contain comparative analysis and interpretation, which cannot be automatically created, and which are highly dependent on the activity's particularities. Thus, the cost saving reaches (892500 ID).

\section{CONCLUSION:}

The cloud concept is getting more popular as time goes by, and increasingly more companies are adopting cloud-based software in order to improve their efficiency and to experience many other benefits. The cloud accounting model 


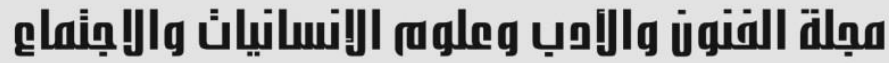

Journal of Arts, Literature, Humanities and Social Sciences

www.jalhss.com

enables all business participants (business owners, accountants, auditors and clients) to closely collaborate by accessing up-to-date financial data at the same time, via the internet. By conducting this study, we aimed to bring attention to the changes implied by the virtualisation of certain operations on the financial accounting process and on the organisation as a whole. A certain advantage of data migration into the cloud is the centralisation of data and information through the integration of organisational processes such as inventory management, fixed assets, and billing also, this results into reduction of workload and time allocated for obtaining results. Another significant impact can be seen at the budget and costs level through substantial saving due to the fact that it is eliminated the need to install IT equipment locally, but in return, the technical function is out sourced.

Moreover, cloud services require a monthly cost to the service provider without being necessary additional costs with depreciation, maintenance or updating of systems and equipment's. Nowadays, the advantages of cloud solutions are becoming more and more visible among companies in terms of technologies that can be used in the business environment. Security aspects also needed to be attended by the company which adopts cloud accounting. 


\section{مهِالة الفiو \\ Journal of Arts, Literature, Humanities and Social Sciences www.jalhss.com \\ Volume (54) July 2020 \\ العدد (54) يوليو 2020}

\section{References}

1- Wyslocka. Elzbieta \& Jelonek. Dorota, 2015, "Accounting in the Cloud Computing", The Online Journal of Science and Technology - October 2015 Volume 5 , Issue 4.

2- Dimitriu \& Matei, 2015, "Cloud accounting: a new business model in a challenging context", Procedia Economics and Finance 32 (2015) 665 - 671.

3- Khanom. Tahmina, 2017, "Cloud Accounting: A Theoretical Overview", IOSR Journal of Business and Management (IOSR-JBM) e-ISSN: 2278-487X, p-ISSN: 2319-7668. Volume 19, Issue 6. Ver. V (June 2017), PP 31-38.

4- Mihalache D. Arsenie-Samoil, 2011, "Cloud Accounting", "Ovidius" University Annals, Economic Sciences Series Volume XI, Issue 2, pp. 782-787.

5- ALLAHVERDİ, Metin, 2017, "Cloud Accounting Systems And A Swot Analysis", The Journal of Accounting and Finance July 2017 Special Issue, pp 92105.

6- Zhang. Ling \& Gu. Wenlin, (2013), "The Simple Analysis of Impact on Financial Outsourcing Because of The Rising of Cloud Accounting”, Asian Journal of Business Management 5(1): 140-143.

7- Onyali, Chidiebele Innocent, 2016, "The Use Of Cloud Computing And Accounting Packages For Corporate Business Transactions In Nigeria: An Explorative Study", IOSR Journal of Business and Management (IOSR-JBM) eISSN: 2278-487X, p-ISSN: 2319-7668. Volume 18, Issue 7 .Ver. II (July 2016), PP 113-117.

8- ZHANG. Cancan, 2014, "Challenges and Strategies of Promoting Cloud Accounting", Management \& Engineering journal homepage: www.seiofbluemountain.com, pp 79-82.

9- Ma. Xinding, 2015, "THE ADOPTION OF CLOUD COMPUTING FOR SMALL AND MEDIUM ACCOUNTING FIRMS", A thesis submitted in partial fulfilment of the requirements for the Degree of Master of Commerce in Accounting in the University of Canterbury .

10- M. Thirmal Rao, T.G.Jyotsna, M.A. Sivani, 2017, "Impact of Cloud Accounting: Accounting Professional's Perspective", IOSR Journal of Business and Management (IOSR-JBM) e-ISSN: 2278-487X, p-ISSN: 2319-7668 PP 53-59. Www.iosrjournals.org

11- Sobhan. Raihan, 2019 "The Concept of Cloud Accounting and its Adoption in Bangladesh", International Journal of Trend in Scientific Research and Development (IJTSRD), Volume: 3 | Issue: 4 | May-Jun 2019 Available Online: www.ijtsrd.com eISSN: $2456-6470$.

12- Dordevic. Milica, Radovic. Ognjen \& Bonic. Ljiljana, 2018, "POTENTIALS FOR APPLYING CLOUD TECHNOLOGY IN ACCOUNTING”, ЕКОНОМИКA, ORIGINAL SCIENTIFIC ARTICLE, Vol. 64, july-september 2018, № 3, p. 23- 32.

13- Kadian. Nishant, 24- 2- 2017, "Cloud Accounting vs. Traditional Accounting: All You Need To Know" https://www.acecloudhosting.com/blog/traditionalaccounting-vs-cloud-accounting/ 


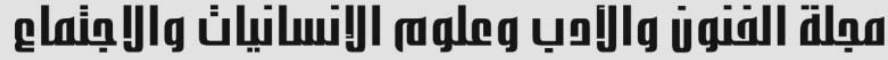

Journal of Arts, Literature, Humanities and Social Sciences

www.jalhss.com

Volume (54) July 2020

العدد (54) يوليو 2020

14- Modi. Prof. Piyush. M., "Cloud Accounting - It's Benefits and Challenges", International Journal of Trend in Scientific Research and Development (IJTSRD) International Open Access Journal, ISSN No: 2456 - 6470| www.ijtsrd.com | Volume $-2 \mid$ Issue -2 .

15- IONESCU. Bogdan \& IONESCU. Iuliana, "TRADITIONAL ACCOUNTING VS. CLOUD ACCOUNTING", Proceedings of the 8th International Conference ACCOUNTING AND MANAGEMENT INFORMATION SYSTEMS AMIS 2013, ISSN 2247-6245, p. 106- 125.

1- https://smallbusiness.chron.com/cloud-accounting-33995.html

2- https://www.alignable.com/orlando-fl/forum/can-anyone-recommend-a-goodaccounting-software-program-for-small/xuerong-liang 